УДК 378.016:786.2.071.2:159.952

DOI:

Сюй Фейфей, аспірант

Національного педагогічного університету імені М.П. Драгоманова, м. Київ

\title{
ПЕДАГОГІЧНІ УМОВИ ФОРМУВАННЯ ВИКОНАВСЬКОЇ УВАГИ МАЙБУТНЬОГО ВЧИТЕЛЯ МУЗИКИ В ПРОЦЕСІ ФОРТЕПІАННОӤ ПІДГОТОВКИ
}

У статті актуалізовано проблему формування виконавської уваги майбутнього вчителя музики 6 процесі фортепіанної підготовки. В результаті проведеного діагностичного етапу дослідження було виявлено ряд проблем щедо рівня сформованості даного феномену, врахування яких дозволило авторові сформулювати педагогічні умови, щзо сприяють інтенсифікаиії формування виконавської уваги студентів. Підкреслено необхідність організації навчання з орієнтацією на усвідомлення й активне засвоєння студентами інформації щодо функиій, механізмів дії та властивостей уваги в діяльності піаніста-виконавия. Наголошено на підсиленні пізнавального інтересу студента до фортепіанного виконавського мистеитва шляхом урахування при підборі репертуару, яким має оволодіти майбутній учитель музики, його вподобань, бажань та можливостей.

Ключові слова: майбутній вчитель музики; виконавська увага; музично-виконавський процес; педагогічні умови; фортепіанна підготовка.

Jim. 8.

Xu Feifei, Postgraduate Student of the National Mukhaylo Drahomanov Pedagogical University, Kyiv

\section{PEDAGOGICAL CONDITIONS OF FORMING OF EXECUTIVE ATTITUDE OF THE FUTURE MUSIC TEACHER IN THE PROCESS OF PIANO PREPARATION}

The article actualizes the problem of forming the executive attention of the future teacher of music in the process of piano training. As a result of the diagnostic stage of the experiment, the author of the study revealed a number of problems regarding the level of formation of this phenomenon in the future specialists. The following negative moments mean are: the loss of the students' interest in musical performance; low interest into the future profession; inefficient division of forces during independent work; underestimation of the role of attention at different stages of the musical-performing process; poor concentration of attention during the performance of the program's work, due to incorrect statement of purpose and low motivation, etc. Consideration of the revealed problems has become crucial in the process of formulating the pedagogical conditions that contribute to the intensification of the formation of executive attention of students. The article emphasizes the need for organization of training with the orientation towards the students' awareness of the role of attention in the musical-performing process. Execution of this pedagogical condition guides the future specialist in the active assimilation of information about the role, functions, mechanisms of action, the properties of performance attention in the activities of a musician-pianist. The obtained knowledge contributes to changes of the student's attitude towards everyday self-study, work in the class of the main musical instrument and concert performance of musical works.

The author emphasizes the enhancement of cognitive interest in piano performing arts. One of the means of realizing this condition is determined by the selection of repertoire, which should be mastered by the future teacher of music, taking into account his preferences, desires and opportunities.

Among other effective pedagogical conditions that have a positive effect on the process of organizing the attention of students and to ensure the achievement of positive changes in this issue, the author calls the creation of an atmosphere of emotional and emotional exaltation and success in the course of creative communication "teacherstudent". As well as encouraging students to the emotionally-volitional self-control while resolving their planned musical and performing tasks. According to the author, the introduction of these pedagogical conditions do not positively mark only in the form of executive attention of future music teachers, but also in the general field of piano training of student.

Keywords: a future teacher of music; the executive attention; musical-performing process; pedagogical conditions; a piano training.

П остановка проблеми. Результати процесів реформації та модернізації, що охопили освітню галузь нашої країни, призвели до виникнення нових підходів у розумінні щодо підготовки педагогічних кадрів молодої генерації вчителів, основною місією яких $\epsilon$ підвищення якості освіти як потужного джерела духовного зростання підростаючого покоління. Зважаючи на це, різні аспекти проблеми фортепіанної підготовки майбутніх учителів музики, основу якої складає удосконалення музично-виконавської діяльності, набувають 


\section{ПЕДАГОГІЧНІ УМОВИ ФОРМУВАННЯ ВИКОНАВСЬКОӦ УВАГИ МАЙБУТНЬОГО ВЧИТЕЛЯ МУЗИКИВ ПРОЦЕСІФОРТЕПІАННОӤ ПІДГОТОВКИ}

статусу актуальних. Зокрема, такою, що потребує сучасного погляду щодо свого вирішення виступає проблема формування виконавської уваги майбутніх учителів музики в процесі фортепіанної підготовки.

У працях видатних педагогів-піаністів минулого століття (Д. Баренбойма, Й. Гофмана, Г. Когана, Н. Любомудрової, К. Мартінсена, Г. Нейгауза, С. Савшинського, А. Щапова та ін.) з різних позицій висвітлено роль, функції та місце уваги в діяльності піаніста-професіонала.

Більш детального висвітлення дана проблема дістала в дослідженнях сучасних науковців 3 галузі музичної психології, де увага музикантавиконавця розглядається як необхідна умова музично-виконавської діяльності (В. Петрушин, Л. Бочкарьов, М. Жижина, О. Лучініна, О. Винокурова, Ю. Цагареллі, Т. Комарова); складова однієї $з$ дев'яти базових здібностей (Д. Кірнарська); елемент у загальному психологічного комплексі музиканта-виконавця (Г. Овсянкіна) тощо.

У сучасній теорії та методиці музичного навчання проблемі виконавської уваги присвячені дослідження Д. Юника, С. Міколінської, 3. Софроній, М. Петренко і Н. Бережної. Різноманітні аспекти цієї проблеми представлені в роботах С. Сливко, В. Гусака, Г. Падалки, О. Рудницької, О. Щолокової та ін. Однак не зважаючи на значущість висвітлених у вказаних роботах питань, проблема формування виконавської уваги майбутнього вчителя музики в процесі фортепіанної підготовки не набула достатнього висвітлення у науково-педагогічній літературі.

Мета статті полягає в теоретичному обгрунтуванні педагогічних умов формування виконавської уваги майбутнього вчителя музики в процесі фортепіанної підготовки.

Виклад основного матеріалу. Під формуванням виконавської уваги ми розуміємо процес становлення майбутнього фахівця під впливом факторів, спрямованих на вдосконалення різних їі властивостей 3 метою покращення якості музично-виконавської діяльності. Одним з таких факторів є створення таких педагогічних умов у навчальному середовищі, що в кінцевому рахунку призведугь до досягнення бажаного педагогічного результату.

"Умова" як філософська категорія відображає універсальні відношення речі до тих чинників, завдяки яким вона виникає й існує; складає середовище, обстановку, в якій виникає, існує і розвивається певне явище або процес [3].

У Великому тлумачному словнику сучасної української мови поняття “умова” розкривається як:
1) вимога, пропозиція, що висувається однією зі сторін, які домовляються про що-небудь;

2) необхідна обставина, яка уможливлює здійснення, створення, утворення чого-небудь або сприяє чомусь;

3) обставини, особливості реальної дійсності, за яких відбувається або здійснюється щонебудь;

4) правила, які існують або встановлені в тій чи іншій галузі життя, діяльності, які забезпечують нормальну роботу чого-небудь;

5) правила, вимоги, виконання яких забезпечує що-небудь;

6) сукупність даних, положення, що лежать в основі чого-небудь [3, 1295].

Визначення поняття “умови" в педагогіці передусім пов'язане з педагогічним осмисленням означеної категорії. У сучасній педагогічній науці розглядаються педагогічні умови впровадження різних педагогічних явищ, формування визначених характерних особливостей учнів, створення певної педагогічної системи, здійснення конкретної педагогічної технології тощо. Зокрема, такі науковці як А. Алексюк, А. Аюрзанайн, П. Підкасистий розуміють під терміном "педагогічна умова" певну обставину, яка впливає (позитивно чи негативно) на формування та розвиток педагогічних явищ, процесів, систем, якостей особистості. Вони класифікують умови за зовнішнім чинником (позитивні відносини викладача і студента; об'єктивність оцінки навчального процесу; місце навчання тощо) та внугрішнім (індивідуальні властивості студентів - стан здоров'я, властивості характеру, досвід, уміння, навички, мотивація тощо) [6].

На думку О. Бражнич, педагогічні умови - це сукупність об'єктивних можливостей змісту, методів, організаційних форм і матеріальних можливостей здійснення педагогічного процесу, що забезпечує успішне досягнення поставленої мети [2].

Досить широке поняття “умова” використовується в дидактиці при характеристиці цілісного педагогічного процесу, окремих його сторін і складових частин. На думку В. Андрєєва, педагогічні умови являють собою результат “цілеспрямованого відбору, конструювання й застосування елементів змісту, методів (прийомів), а також організаційних форм навчання для досягнення дидактичних цілей” $[1,124]$.

У дослідженнях Н. Данько педагогічні умови розглядаються як усвідомлено, цілеспрямовано створені обставини, за наявністю яких стає можливим досягнення певного якісного результату педагогічної діяльності. 


\section{ПЕДАГОГІЧНІ УМОВИ ФОРМУВАННЯ ВИКОНАВСЬКОЇ УВАГИ МАЙБУТНЬОГО ВЧИТЕЛЯ МУЗИКИВ ПРОЦЕСІФОРТЕПІАННОӤ ПІДГОТОВКИ}

У монографії “Педагогіка мистецтва" Г. Падалка розглядає особливості, сутність педагогічних умов навчання мистецтва та визначає їх як "цілеспрямовано створені чи використовувані обставини мистецького навчання, що забезпечують можливість досягнення його результативності”. Педагогічні умови науковець розглядає як складову частину методики $[7,160]$.

Зрозуміло, що спільною рисою зазначених визначень даної категорії є спрямованість на вдосконалення взаємодії учасників педагогічного процесу при вирішенні конкретних навчальних завдань. Тож, у нашому дослідженні педагогічні умови виступають одним із факторів, що забезпечують організацію взаємодії об'єктів навчально-виховного процесу щодо досягнення поставленої мети та прогнозованого результату.

Проведений діагностичний етап дослідження виявив ряд проблем щодо рівня сформованості виконавської уваги в майбутніх фахівців. Зокрема, окреслились негативні моменти, представленні: втрачанням інтересу студентів щодо музичновиконавської діяльності; нейтральним, незацікавленим ставленням до майбутньої професії; неефективним розподілом сил під час самостійної роботи, що веде повільних темпів опанування творами програми; недооцінкою ролі уваги на різних етапах музично-виконавського процесу; слабкою концентрацією уваги під час виконання творів програми, пов'язаною з невірною постановкою мети та відсутністю чіткого плану виконавських дій тощо. Врахування виявлених проблем стало визначальним у процесі формулювання педагогічних умов, які мають позитивним чином позначитись на процесі організації уваги студентів і забезпечити досягнення позитивних зрушень уданому питанні.

Ураховуючи значущість об'єктивно існуючої проблеми та спираючись на інформацію, отриману в ході проведеного експериментального дослідження, було визначено ряд ефективних і дієвих педагогічних умов, урахування яких сприяє інтенсифікації формування виконавської уваги майбутніх вчителів музики. Серед них:

- організація навчання з орієнтацією на усвідомлення студентами ролі уваги в музичновиконавському процесі;

- підсилення пізнавального інтересу до фортепіанного виконавського мистецтва;

- створення атмосфери емоційно-почуттєвого піднесення й успіху в ході творчої комунікації “викладач-студент";

- спонукання студентів до емоційно-вольового самоконтролю під час рішення намічених музично-виконавських завдань.
Розглянемо кожну з них детальніше.

Перша педагогічна умова орієнтує майбутнього фахівця на активне засвоєння інформації щодо ролі, функцій, механізмів дії, видових характеристик виконавської уваги в діяльності музиканта-піаніста. Отримані знання сприяють усвідомленню взаємозв'язку “уважність-якість”, що призводить до змін у ставленні студента щодо повсякденних самостійних занять, роботи в класі основного музичного інструменту та концертного виконання музичних творів. Такі зміни зумовлені результатами, отриманими студентом під час “зосереджених” самостійних занять, які дозволили вирішувати поставлені викладачем виконавські завдання за менший відрізок часу ніж за попередніх часів роботи. Тобто вони на власному досвіді відчули яким чином зосередженість уваги в репетиційній роботі впливає на підвищення загальної ефективності музично-виконавської діяльності.

Варто наголосити саме на процесі усвідомлення інформації студентом, а не розумінні чи ознайомленні $з$ нею. Оскільки усвідомлення передбачає певний стан свідомості, що включає дію, в результаті якої людина здатна глибоко бачити те, що відбувається 3 нею. Втім як міркування (ментальний рівень усвідомлення) забезпечує лише усвідомлення думок без усвідомлення дій або почуттів. Тобто в такому випадку є місце для суперечностей між тим, що людина говорить, відчуває та як діє. Усвідомлення ж веде до узгодженості зовнішніх і внутрішніх факторів - дій, почуттів, думок. Тому, за нашим переконанням, саме $з$ усвідомлення студентом значущості уваги у музично-виконавському процесі та власних особливостей даного феномену відбувається перший крок на шляху до його ефективного формування та удосконалення.

Застосування другої педагогічної умови обумовлено прямо пропорційною залежністю ступеня концентрації та стійкості уваги від наявного інтересу суб'єкта до предмету уваги. Тому надзвичайно важливо під час навчальновиховного процесу підтримувати ступінь зацікавленості студента щодо виконавської діяльності та майбутньої професії. На думку М. Жижиної максимальний інтерес до роботи оживляє увагу, сприяє підвищенню її концентрації, так само як спаду уваги передує втрата інтересу до діяльності [4].

Одним з засобів реалізації даної умови є вибір репертуару, яким має оволодіти майбутній учитель музики, з урахуванням вподобань, бажань та можливостей студента. Основна 


\section{ПЕДАГОГІЧНІ УМОВИ ФОРМУВАННЯ ВИКОНАВСЬКОЇ УВАГИ МАЙБУТНЬОГО ВЧИТЕЛЯ МУЗИКИВ ПРОЦЕСІФОРТЕПІАННОӤ ПІДГОТОВКИ}

вимога - щоб обрані твори викликали бажання їх вивчити й інтерес “спортивного” (Чи зможу опанувати технічно складний твір?) або “художньо-виконавського” (Чи зможу передати зміст? Донести ідею? Розкрити образ?) плану. Негативне або байдуже ставлення до виконуваної музики ускладнить та уповільнить процес іiі вивчення, а отже і гальмуватиме формування виконавської уваги.

Серед інших засобів посилення пізнавального інтересу майбутнього фахівця до фортепіанного виконавства слід назвати: залучення студентів до відвідування концертів піаністів, перегляду відеозаписів або прослуховування різних виконавських трактовок творів 3 подальшим обговоренням; спонукання до пошуку цікавих фактів 3 життя композиторів, твори яких вони виконують; формування непрямих інтересів (наприклад, до результату діяльності- отримання додаткових балів за виступи на заходах просвітницького характеру (в музеях, бібліотеках).

Наступна педагогічна умова також тісно пов' язана зі стимулюванням інтересу студента до занять, але більше торкається питань мотиваційної сфери особистості, яке у музичній педагогіці $є$ вагомим і має вирішальне значення на результат роботи й ефективність взаємодії.

У науковій літературі мотивація визначається одним з найважливіших компонентів у структурі людської діяльності. У ряді психологічних досліджень (В. Петрушина, Л. Бочкарьова, Д. Кірнарської, М. Жижиної на ін.) неодноразово підкреслювалася важливість мотивації для протікання психічних процесів, у тому числі й уваги. Зокрема, М. Жижина, аналізуючи діалектичний зв'язок мотивації й уваги, дійшла висновків про те, що мотивація:

- сприяє збільшенню часу стійкого та продуктивного зосередження, а також зменшує кількість відволікань уваги від предмету занять;

- здатна активізувати увагу в період зниження іiі активності;

- веде до позитивної динаміки уваги;

- розширює сферу зосередження уваги та сприяє цілеспрямованому регулюванню уваги;

- змінює пасивний стан на активність, з іншого боку - активність уваги сприяє підвищенню мотивації в періоди її зниження;

- неминуче веде до позитивного зрушення в динаміці уваги;

- викликає відповідний оптимальний рівень зосередження уваги на предметі музичної діяльності [4, 55 - 56].

У контексті визначеної нами третьої педагогічної умови особливої значущості набуває формування в майбутнього фахівця мотивації досягнення успіху. Адже особистість, мотивована на досягнення успіху, має чіткі позитивні цілі, активне послідовне прагнення щодо їх досягнення, упевненість у власних силах і можливостях, вірну самооцінку. С. Макаренко, досліджуючи проблему формування мотивації досягнень в структурі мотиваційної сфери особистості вчителя, наголошує, що вона носить позитивний характер і спрямовує дії людини на досягнення конструктивних, позитивних результатів, що в свою чергу викликає позитивні емоції. Автор дослідження робить висновок про те, що “мотивація досягнення успіху - це стратегія поведінки людини, коли він орієнтований на активність, досягнення результату, не боїться помилок, вживає різні дії, здатний до ризику” [5 , 317]. А iï формування у вчителів “дає змогу ефективно самореалізовуватися через оптимальні стратегії поведінки, розвиваючи аксіологічний, компетентнісний, особистісний, поведінковий, рефлексивний, комунікативний та емоційновольовий компоненти власної особистості в цілому та як професіонала" [5, 321].

Реалізація останньої педагогічної умови передбачає спонукання студента до свідомої мобілізації власних психічних і фізичних можливостей $з$ метою подолання труднощів під час концертного виступу. Емоційно-вольовий контроль виявляється в двох взаємопов'язаних функціях - спонукальній (забезпечує активність людини і характер іiі дій відповідно до свідомо поставленої мети) та гальмівної (сприяе стримуванню небажаних проявів активності). Завдяки цьому дія одних мотивів підсилюється, a інших гальмується, долаються зовнішні перешкоди та внутрішні утруднення.

Науково доведено, що мобілізація вольових зусиль дозволяє вдвічі збільшити ефективність діяльності, а найбільший успіх забезпечується при позитивній мотивації та докладені вольових зусиль, які виявляються у таких властивостях як організованість, рішучість, ініціативність, наполегливість, самостійність, витримка тощо.

За В. Петрушиним, “контроль $є$ системою дій, що лежать в основі довільної уваги” [8, 118]. Дослідник підкреслює, що основна його функція полягає в тому, щоб контролювати відповідність задуманого з реальними діями виконавця. На думку науковця саме контроль дозволяе спрямувати увагу на досягнення бажаної мети. Вагомою для нашого дослідження є позиція В. Петрушина щодо переходу контролю в увагу при ідеальному скороченні й автоматизації дії, що 


\section{ПЕДАГОГІЧНІ УМОВИ ФОРМУВАННЯ ВИКОНАВСЬКОЇ УВАГИ МАЙБУТНЬОГО ВЧИТЕЛЯ МУЗИКИВ ПРОЦЕСІФОРТЕПІАННОӤ ПІДГОТОВКИ}

дозволяє в такому разі увазі перетворитися на автоматизовану дію контролю. Це є одним із визначальних факів, що підтверджують необхідність та дієвість сформульованої нами педагогічної умови, спрямованої на розвиток здатності студента щодо емоційно-вольового самоконтролю під час музично-виконавської роботи.

Висновки. Підсумовуючи, зазначимо, що впровадження вищерозглянутих педагогічних умов позитивним чином позначається на формуванні виконавської уваги майбутніх учителів музики, а також на якості фортепіанної підготовки студентів. Адже вони торкаються найбільш актуальних і розповсюджених проблем сучасної музично-педагогічної освіти.

\section{ЛІТЕРАТУРА}

1. Андреев В. И. Педагогика высшей школы. Инновационно-прогностический курс: учеб. пособие / В. И. Андреев. - Казань: Центр инновационных технологий, 2013. -500 с.

2.БражничО.Г.Педагогічніумови диференційованого навчання учнів загальноосвітньої школи: дис. ... канд. пед. наук: спец. 13.00.07 “Теорія і методика виховання” / О. Г. Бражнич. - Кривий Ріг, 2001. $238 \mathrm{c}$.

3. Великий тлумачний словник сучасної української мови / Укл. і головний ред. В. Т. Бусел. - К.; Ірпінь: ВТФ “Перун”, 2004. - 1440 с.

4. Жижина М. В. Психолого-педагогические условия и факторы формирования исполнительского внимания музыканта / М. В. Жижина. - Саратов: Изд-во Саратовского университета, 2002. - 138 с.

5. Макаренко С. С. Формування мотивації досягнень в структурі мотиваційної сфери особистості вчителя [Електронний ресурс] / С. С.Макаренко. // Науковий вісник Львівського державного університету внугрішніх справ. - 2013. - Режим доступу до ресурсу: http:// www2.1vduvs.edu.ua/documents pdf/visnyky/nvsp/ 01 2013/13msssov.pdf

6. Організація самостійної роботи студентів в умовах інтенсифікації навчання: навч. посіб. / А. М. Алексюк, А. А. Аюрзанайн, П. І. Підкасистий, [та ін.]. - К.: ІСДО, 1993. - 336 с.

7. Падалка Г. М. Педагогіка мистецтва: теорія і методика викладання мистецьких дисциплін / Г. М. Падалка. - К.: Освіта України, 2008. - 274 с.

8. Петрушин В. И. Музыкальная психология:
Учебное пособие для вузов / В. И. Петрушин.М.: Академический Проект; Трикста, 2008. - 400 с. $-(2)$.

\section{REFERENCES}

1. Andreev, V. I. (2013). Pedagogika vysshey shkoly. Innovatsionno-prognosticheskiy kurs [Pedagogy of the higher school. Innovationforecasting course]. Kazan: Center for Innovative Technologies, 500 p. [in Russian].

2. Brazhnych, O. H. (2001). Pedahohichni umovy dyferentsiovanoho navchannia uchniv zahalnoosvitnoi shkoly [Pedagogical conditions of differentiated teaching of pupils of a secondary school]. Kryvyi Rih, 238 p. [in Ukrainian].

3. Busel, V. T. (2004). Velykyi tlumachnyi slovnyk suchasnoi ukrainskoi movy [Great explanatory dictionary of modern Ukrainian language]. Kyiv, Irpin: VTF “Perun” Publ., 1440 p. [in Ukrainian].

4. Zhizhina, M. V. (2002). Psikhologopedagogicheskie usloviya i faktory formirovaniya ispolnitelskogo vnimaniya muzykanta [Psihologopedagogical conditions and factors of formation of performing attention of the musician]. Saratov: Saratov University, 138 p. [in Russian].

5. Makarenko, S. S. (2013). Formuvannia motyvatsii dosiahnen $\mathrm{v}$ strukturi motyvatsiinoi sfery osobystosti vchytelia [Formation of the motivation of achievements in the structure of the teacher's personality motivational sphere]. Scientific journal "Scientific herald". Series psychology. Lviv: Lviv State University of Internal Affairs, pp.314-323. [in Ukrainian].

6. Aleksiuk, A. M., Aiurzanain, A. A. \& Pidkasystyi, P. I. et al. (1993). Orhanizatsiia samostinoi roboty studentiv $v$ umovakh intensyfikatsii navchannia [Organization of independent work of students in conditions of intensification of training]. Kyiv: ISDO Publ., 336 p. [in Ukrainian].

7. Padalka, H. M. (2008). Pedahohika mystetstva: teoriia $i$ metodyka vykladannia mystetskykh dystsyplin [Pedagogy of art: theory and methodology of teaching artistic disciplines]. Kyiv: Education of Ukraine Publ., 274 p. [in Ukrainian].

8. Petrushin, V. I. (2008). Muzykalnaya psikhologiya [Musical psychology]. Moscow: Academic project; Triksta Publ., (2), 400 p. [in Russian].

Стаття надійшла до редакції 16.07.2018

\section{G5808nc2

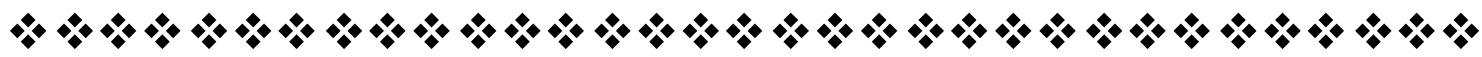

